\title{
Review \\ Lyme Neuroborreliosis: Mechanisms of B. burgdorferi Infection of the Nervous System
}

\author{
Lenzie Ford ${ }^{1, *}$ and Danielle M. Tufts ${ }^{2, *(1)}$ \\ 1 Neuroscience Research Institute, University of California, Santa Barbara, CA 93106, USA \\ 2 Infectious Diseases and Microbiology Department, Graduate School of Public Health, \\ University of Pittsburgh, Pittsburgh, PA 15261, USA \\ * Correspondence: lenzieford@ucsb.edu (L.F.); dmt80@pitt.edu (D.M.T.)
}

Citation: Ford, L.; Tufts, D.M. Lyme Neuroborreliosis: Mechanisms of B. burgdorferi Infection of the Nervous System. Brain Sci. 2021, 11, 789 https://doi.org/10.3390/ brainsci11060789

Academic Editors: Allan Bieber and Lucia Lisi

Received: 4 April 2021

Accepted: 9 June 2021

Published: 15 June 2021

Publisher's Note: MDPI stays neutral with regard to jurisdictional claims in published maps and institutional affiliations.

Copyright: () 2021 by the authors. Licensee MDPI, Basel, Switzerland. This article is an open access article distributed under the terms and conditions of the Creative Commons Attribution (CC BY) license (https:// creativecommons.org/licenses/by/ $4.0 /)$.

\begin{abstract}
Lyme borreliosis is the most prevalent tick-borne disease in the United States, infecting $\sim 476,000$ people annually. Borrelia spp. spirochetal bacteria are the causative agents of Lyme disease in humans and are transmitted by Ixodes spp ticks. Clinical manifestations vary depending on which Borrelia genospecies infects the patient and may be a consequence of distinct organotropism between species. In the US, B. burgdorferi sensu stricto is the most commonly reported genospecies and infection can manifest as mild to severe symptoms. Different genotypes of B. burgdorferi sensu stricto may be responsible for causing varying degrees of clinical manifestations. While the majority of Lyme borreliae-infected patients fully recover with antibiotic treatment, approximately $15 \%$ of infected individuals experience long-term neurological and psychological symptoms that are unresponsive to antibiotics. Currently, long-term antibiotic treatment remains the only FDA-approved option for those suffering from these chronic effects. Here, we discuss the current knowledge pertaining to B. burgdorferi sensu stricto infection in the central nervous system (CNS), termed Lyme neuroborreliosis (LNB), within North America and specifically the United States. We explore the molecular mechanisms of spirochete entry into the brain and the role B. burgdorferi sensu stricto genotypes play in CNS infectivity. Understanding infectivity can provide therapeutic targets for LNB treatment and offer public health understanding of the B. burgdorferi sensu stricto genotypes that cause long-lasting symptoms.
\end{abstract}

Keywords: Lyme disease; Borrelia burgdorferi; infectious disease; tick-borne pathogen; post-treatment Lyme disease syndrome; neurotropism

\section{Introduction}

Lyme disease is the most common tick-borne disease in North America and Europe, affecting over half a million people annually [1-4]. Lyme disease is caused by Borrelia spp. spirochetal bacteria and transmitted by Ixodes spp. ticks $[5,6]$. The most common symptoms include the presence of a skin rash (erythema migrans) at the tick bite site, as well as fever, headache, and fatigue [7-10]. If not treated with antibiotics, Lyme disease can persist and the patient may develop neurological, cardiac, chronic skin, or articular symptoms [10-14]. This review focuses on the later-stage neurological symptoms that can arise from Lyme disease infection in humans from North America.

The first discovery of a neurological symptom from Lyme disease infection was a 1922 finding of meningoradiculitis occurring after a tick bite [11,15]. Lyme neuroborreliosis (LNB), or Lyme disease-causing symptoms of the central and peripheral nervous system, is multifaceted and patients generally present with meningitis, cranial neuritis, radiculoneuritis, parenchymal inflammation of the brain or spinal cord, peripheral neuropathy, and/or encephalopathy [12,16-18]. In Europe, where the first meningoradiculitis findings occurred, Bannwarth Syndrome (also known as Garin-Bujadoux-Bannwarth syndrome) has been characterized in which LNB manifests as severe radicular pain accompanied by 
cranial nerve paresis [17]. Occasionally confusion and central nervous system dysfunction occur, while meningeal and encephalitic features are rare $[16,19,20]$. LNB is caused by the Borrelia burgdorferi sensu lato complex which includes the species: B. garinii, B. afzelii (common in Europe), and B. burgdorferi sensu stricto (ss) (common in North America) [21-23]. Minimal Bannwarth syndrome cases have been reported in North America and most LNB manifestations differ between continents, possibly as a result of the different genospecies of Borrelia that are present in these locations [8,24]. For this reason, we focus on rare North American B. burgdorferi ss LNB which affects $10-20 \%$ of patients $[19,25,26]$. The estimated number of cases in the US was nearly 2 million cases in 2020 [27]. Recently, various LNB cases have been reported in Minnesota and Wisconsin [28]; indicating that cases may be increasing in the US. In western Pennsylvania from 2003 to 2013, neurological symptoms were observed in $12 \%$ of Lyme-infected patients [29]. This study also showed that cases of pediatric Lyme disease doubled every 1.6 years [29]. Collectively, these data indicate a rising precedence of LNB in the United States and underscore the importance of studying this disease.

North American LNB largely manifests as lymphocytic meningitis, cranial neuritis, radiculoneuritis, and/or mononeuritis multiplex [9-14,16,17,19,20,22,26,30-39]. Antibodies in response to B. burgdorferi ss infection can persist in the cerebrospinal fluid (CSF) for several weeks or in serum for several years $[40,41]$. Within the first few weeks of infection, disruptions to cortex function have been measured as magnetic resonance imaging (MRI)-identified hyperintensities and positron emission tomography (PET)-identified mild-moderate hypometabolism $[37,42,43]$. Psychological symptoms are also present in this early stage (3-32 days), consisting of depression, decreased concentration, sleep disturbance, and memory impairment [44]. Post-B. burgdorferi ss infection stages (several weeks to months) can manifest as more severe neurological and psychological disruptions, including distal paresthesias, chronic encephalomyelitis, panic attacks, severe dementias, personality changes, catatonia, and mania [37,39,44]. Currently, antibiotic treatment is the only FDA-approved treatment method available for Lyme disease; however, LNB presents in the late stage of infection and tends to be resistant to antibiotics [45,46]. LNB that is antibiotic unresponsive, also called post-treatment Lyme disease syndrome (PTLDS), affects $10-20 \%$ of disease patients $[17,30,39,45-51]$. The prevalence of late-stage LNB and the lack of agreement amongst clinicians for treatment options punctuates the need for further mechanistic and translational studies of LNB.

\section{B. burgdorferi ss Transmission Cycle and the Importance of Outer-Surface Proteins}

The transmission of B. burgdorferi ss bacteria from host-tick-host is an intricate and complex process which requires spatial and temporal gene regulation of the bacteria to adapt to the vector biological environment and evasion of the host innate immune system $[52,53]$. White-footed mice, Peromyscus leucopus, are the most effective reservoir hosts of B. burgdorferi ss in North America; however, other small- and medium- sized mammals and several avian species may also serve as competent hosts [54-65]. Reservoir hosts generally experience persistent asymptomatic infections and B. burgdorferi ss may utilize various mechanisms to effectively evade the host innate immune response $[65,66]$. Transmission occurs predominantly via hard-bodied ticks in the Ixodes genus [67-69]. When a larval tick takes a bloodmeal from an infected host, it may acquire B. burgdorferi ss spirochetes. The engorged larva will molt into the nymphal life stage and will subsequently infect susceptible hosts including humans $[6,10,12]$. Transmission of spirochetal bacteria from tick vector to a susceptible host begins during bloodmeal uptake. Various borrelial outer surface proteins (Osp) play important roles in pathogen virulence, transmission, and survival within the host and vector. In unfed ticks, OspA and $\mathrm{OspB}$ are expressed and promote adherence and survival of spirochetes in the tick midgut between bloodmeals [10,70,71]. Spirochetes are sequestered in the tick midgut by expressing OspA and binding to a tick protein (TROSPA) present in tick gut epithelial cells [72-74]. During a bloodmeal uptake, spirochetes in the midgut begin to multiply rapidly, expression of OspA on the surface decreases, and an 
increase in OspC expression promotes the migration of spirochetes to the tick salivary glands [75-77]. OspC is crucial in the early phase of B. burgdorferi ss infection to evade the host innate immune system; expression decreases after 2-3 weeks in response to host antibodies [52,78-82]. OspC also plays a role in the attachment of spirochetes to the tick salivary protein Salp15, enhancing the spirochete load and protecting them from the host complement system by impairing the function of macrophages, neutrophils, and dendritic cells $[77,83-88]$.

The $\operatorname{sspC}$ gene is hypervariable with genotypes varying in their genetic sequences, geographic distribution, host preferences, pathogenicity, and disease phenotypes [59,89-92]. Over 35 unique $B$. burgdorferi ss OspC genotypes are currently recognized, some of which cause the typical erythema migrans rash and others disseminate through the bloodstream or CNS and are associated with severe disease (A, B, I, K human invasive genotypes) $[23,24,89,90,93-99]$, suggesting that only certain strains may exhibit neurotropism. Disease severity is dependent on several factors including genotype virulence, the abundance of spirochetes present in the tissue, co-infection with other B. burgdorferi ss genotypes and tick-borne pathogens, and intrinsic differences in host immune responses $[21,93,97,100-104]$. Ticks may be simultaneously infected with five or more $B$. burgdorferi ss genotypes [105-109]; however, the number of genotypes a tick is able to transmit during feeding is currently unclear. Certain B. burgdorferi ss genotypes may disseminate through the host system more rapidly than others, they may compete against each other effectively eliminating less efficient genotypes from the host, or they may facilitate infection allowing additional genotypes to thrive [110,111]. Co-infections with other tick-borne pathogens are also common in I. scapularis ticks and reservoir hosts (i.e., Anaplasma phagocytophilum, Babesia microti, Bartonella spp., other Borrelia spp., Ehrlichia muris, Powassan virus, etc.) which may also affect pathogen prevalence, persistence, and transmission efficiency [112-116]. Borrelia burgdorferi ss genotype genetic diversity is thought to be maintained through vertebrate hosts which may act as species specific niches $[59,65,90,117]$.

\section{Gene Specificity Allows for B. burgdorferi ss Infectivity of Brain Cells}

Borrelia spp. genomes are complex, consisting of circular and linear plasmids along with a linear chromosome of $\sim 900 \mathrm{~kb}$ [118]. Different species and genotypes contain a variable number of plasmids due to frequent reorganization and deletion; most of the genes required for metabolism and regulation are found on the linear chromosome, with a few protein encoding genes for growth and specific virulence factors being located on the plasmids [119-123]. The presence or absence of specific plasmids has been linked to infectivity in hosts [124] and specific plasmids or plasmid combinations may be necessary for LNB infection.

Various studies have identified numerous genes and proteins important for B. burgdorferi ss infection and host complement evasion in mammals [65,125-130]. In large part, these studies focus on skin, blood, and joint tissues. These data have provided a wealth of information that suggests strain specificity is critical to infection of different host species. Borrelia burgdorferi ss strains may be classified in several ways including the polymorphic ospC gene, the ribosomal DNA spacer restriction fragment-length polymorphism genotypes (RSTs), and the rrs-rrlA rDNA intergenic spacer (IGS) region [24,106,107] (Table 1). Complete classification for each B. burgdorferi ss strain is lacking and it is unclear how different combinations of these genes and regions may contribute to the variation in human invasive genotypes and LNB.

Table 1. Currently known human-infecting Borrelia burgdorferi strains with corresponding typing classification.

\begin{tabular}{ccccc}
\hline Strain & OspC & RST & IGS & Source \\
\hline B31, 2-39 & A & I & 1 & Bunikis et al., 2004; \\
2206617 & A & I & 11 & Travinsky et al., 2010 \\
\end{tabular}


Table 1. Cont.

\begin{tabular}{ccccc}
\hline Strain & OspC & RST & IGS & Source \\
\hline CA4, CA6 & A & I & 10 & Travinsky et al., 2010 \\
Whang et al., 2002 \\
BL206, BL203, BL268, B479, B491, B515 & A & I & - & Lin et al., 2002 \\
HII, IP1-3, P1F, L5, TXGW, MI2, Pka & A & I & - & Bunikis et al., 2004 \\
I-24 & B & I & 3 & Lin et al., 2002 \\
61BV3, BUR, DK7, Pbre, 35B808, OC2 & B & I & - & Travinsky et al., 2010 \\
64b, B373 & Ba & I & 3 & Travinsky et al., 2010 \\
51405UT & Ba & I & 6 & Travinsky et al., 2010 \\
ZS7 & Bb & I & 16 & Bunikis et al., 2004 \\
4-55/HB19 & I & III & 7 & Lin et al., 2002 \\
OC10 & I & I & - & Travinsky et al., 2010 \\
B500, B331 & Ia & III & 7 & Travinsky et al., 2010 \\
WI91-23 & Ia & III & 7 & Travinsky et al., 2010 \\
CA92-1096 & Ib & III & 7 & Bunikis et al., 2004; \\
297, I-65 & K & II & 2 & Travinsky et al., 2010 \\
149901 & K & II & 14 & Travinsky et al., 2010
\end{tabular}

OspC = outer-surface protein C; RST = ribosomal DNA spacer restriction fragment-length polymorphism genotypes (RSTs); IGS = rrs-rrlA rDNA intergenic spacer region.

Spirochetal infection of the nervous system is further complicated because B. burgdorferi gene expression can be distinct in host blood compared to CSF [96,131,132]. For example, OspA is known to be downregulated in the skin and blood of the host, yet CSF OspA levels are upregulated in early stages of the disease [131]. In a study by Schutzer and colleagues [131], antibody levels against B. burgdorferi OspB and OspC increased during early infection. However, as the disease progressed to the late stage, only $23 \%$ of patients contained antibodies against OspC in their CSF. This work underscores the need for LNB studies to be measured in nervous system tissues.

\section{Mechanisms of B. burgdorferi ss Entrance into the Nervous System}

Borrelia burgdorferi ss strain specificity plays an important role in infectivity of the nervous system. While strain specificity remains a critical question in the field, various studies have identified methods of B. burgdorferi ss entry into the nervous system [133-135]. First, spirochetes enter the CNS via the bloodstream or peripheral nervous system and can be recovered from human CSF 14-18 days post-tick bite [136-139]. The presence of spirochetes in the CSF is a key factor for LNB development, as it provides an access point to the brain. Next, B. burgdorferi ss infiltrate the protective membranous meninges in animal models of Lyme disease [134,135], identifying the first point of brain penetration. Specifically, spirochetes are present in vascular, perivascular, and extravascular regions of the dura mater [134]. Spirochete presence is associated with an increase in T cells and leukocytes within the meninges [134,135].

The host immune response plays an important role in early stages of LNB [52,140-144]. Short-term infection of Rhesus macaque frontal cortex tissue by B. burgdorferi ss ( $24 \mathrm{~h}$ ) and subsequent transcriptomic analysis identified over 2200 genes that were significantly altered, primarily those involved in immune and inflammatory response pathways [145]. Some early inflammatory responses arise from glial cells in the brain and are measured as an increase in cytokine and chemokine markers [146,147]. Alongside this early inflammation, an increased production of the pro-inflammatory cytokine astrocytic interleukin 6 (IL-6) can be measured, as well as oligodendrocyte and neuronal death [146-148]. Borrelia burgdorferi ss caused direct inflammation and apoptosis of the oligodendrocytes, but neuronal death was dependent on microglial activation [148]. These experiments identify the immediate inflammatory response in the animal brain as a result of B. burgdorferi ss infection, and attempt to explain the cell-type specificity that causes this inflammation.

While acute LNB is marked by the host immune response, long-term LNB may disrupt additional molecular pathways in the nervous system. Bouquet et al. [129] tracked the transcriptomic CSF profile of North American Lyme disease patients at the point of 
diagnosis and again 6 months after antibiotic treatment. Pre-treated transcriptomes exhibited a change in over 1000 genes, with approximately $60 \%$ upregulated. Post-treatment transcriptomes still exhibited a change in nearly 700 genes, with approximately $50 \%$ of them being upregulated. Interestingly, inflammatory response and immune cell trafficking pathways were decreased post-treatment [129]. A decrease in the inflammatory and immune pathways in the dura mater was also observed over time in a mouse model of Lyme disease [135]. This post-treatment, antibiotic-resistant stage of LNB seems to be triggered by neither inflammatory nor immune response pathways. It is this stage of LNB that is considerably understudied and requires new mechanistic insight to identify avenues for clinical intervention. Currently, the FDA-approved treatment for LNB in humans is long-term antibiotic treatment; however, numerous clinical studies have found that some patients do not recover from LNB symptoms with this treatment method $[45,46]$. Approximately $10-20 \%$ of patients claim to suffer from persistent Lyme disease-like symptoms months to years following appropriate antibiotic treatment. Chronic Lyme, or the more acceptable term post-treatment Lyme disease syndrome (PTLDS), is steeped in controversy as no evidence of systemic B. burgdorferi infection can be found in these patients and prolonged antibiotic treatments may be detrimental to the health of these patients. While a plethora of data exist on the controversies surrounding these types of patients [149-152], this is not the focus of this review.

\section{Informative Post-Treatment Lyme Disease Genes and Antibiotic-Resistant LNB}

Many studies of LNB tend to focus on the initial inflammatory symptoms of the disease, but for PTLDS, other pathways appear to be involved in the persistent neurological symptoms. Transcriptomic analysis of human CSF from 6 month post-treatment North American LNB identified that the eukaryotic initiation factor 2 (eIF2) pathway remains disrupted [129], suggesting that there may be long-term deficits in the cellular stress response of infected cells. Disruption of this pathway has been linked to a rare genetic colorectal cancer [153]. Additionally, four genes distinguished post-treatment patients with resolved symptoms from patients with persistent symptoms: MIAT, CCDC163P, ZNF266, and GPR15 [129]. Of the genes identified, only GPR15 is associated with an immune response [154]. GPR15 is a G-protein coupled receptor that acts as a chemokine receptor for human immunodeficiency virus (HIV) 1 and 2, and has been implicated in various lymphomas [154]. CCDC163P and ZNF266 are involved in protein binding, with the latter possibly involved in transcription regulation [129]. ZNF266 is also involved in nucleic acid binding, as is MIAT and eIF2 which bind lncRNA and tRNA, respectively [155]. MIAT is involved in multiple human diseases, including myocardial infarction susceptibility, schizophrenia, and substance abuse [155]. These disrupted genes are worth further investigation and may provide insight into how post-treatment Lyme disease symptoms persist in the human brain.

While extremely informative, mRNA transcriptome profiling does not provide a complete picture of LNB. There is a high likelihood that PTLDS may be regulated in part by non-coding RNAs [129]. Future studies need to expand the scope of analysis to include noncoding nucleic acids and proteins. In a cultured human astrocyte study, Casselli et al. [156] measured disruption of mRNA and miRNA levels in acute and long-term B. burgdorferi ss infection. Similar to Ding et al. [145] and Bouquet et al. [129], Casselli and colleagues found upregulation of mRNA involved in inflammation pathways in acute infection. The miRNA alterations, however, provided new insights; long-term infection upregulated miRNA involved in various signaling pathways and cell adhesion. The authors identified hsa-miR-143-3p as a key differentially expressed factor, as it was also involved in chronic fatigue syndrome/myalgic encephalomyelitis, which share symptoms with LNB [156]. This study highlights the importance of investigating non-coding RNAs in Lyme disease, and the long-lasting changes in RNA profiles of posttreatment LNB.

Cell culture studies raise an important consideration for post-treatment LNB experiments: are the persisting symptoms a reaction to meningeal infection or does long-term 
LNB arise from further spirochete penetration into the brain? In vitro, B. burgdorferi ss binds to neurons, glia, and extracellular matrix proteins, highlighting the possibility of penetrance beyond the blood-brain barrier [138,157-161]. Although spirochete presence in brain parenchyma was not observed in mouse models [135], various neurological studies of human brain find B. burgdorferi ss spirochete deposition in the gray matter of the cerebral cortex [162-170], with similar findings to those from in vitro cell culture studies [166]. These data suggest that persistent LNB symptoms may arise from alterations beyond the downstream meningeal inflammatory response and are possibly influenced by spirochete presence and B. burgdorferi ss DNA deposition in brain cells [159,162-164,168,169].

\section{Conclusions and Future Directions}

LNB is an extremely complicated disease: from the strain infectivity of the various genotypes of the B. burgdorferi ss spirochete, to its ability to move from the host bloodstream to the nervous system, to neurotropisms that allow penetrance of the blood-brain barrier and downstream acute inflammatory and immune response, and finally to long-lasting changes in cell adhesion and signaling pathways that coincide with spirochete deposition in the brain. Here, we propose a basic science approach to investigating post-treatment LNB.

First, there is a lack of information regarding which $B$. burgdorferi ss strains are most infectious to the human brain. The OspC genotypes A, B, I, and K are the most infectious in humans [89], but is there an OspC genotype that promotes brain infectivity? Do different combinations of B. burgdorferi ss genes and plasmids contribute to strain invasiveness and neurotropism? Laboratory studies often utilize the Bb-297 strain which was isolated from an LNB patient $[135,171]$ and may not fully encompass all infectious genetic elements due to loss and reorganization of plasmids and genes over time. Furthermore, OspC is not the only Osp protein to be upregulated in human CSF after infection; OspA and OspB are also upregulated [70,71,76,131]. Additionally, erp genes (OspE-F-related lipoproteins) function as receptors for complement inhibitory factor $\mathrm{H}$ molecules and may contribute to the ability of B. burgdorferi spirochetes to evade the host innate immune system [172-174]. Investigating the role of other Osp proteins is necessary for fully understanding LNB infection, particularly OspA which can tether spirochetes to the meninges [134]. Additionally, RSTs and IGS sequences are used to distinguish strain infectivity $[24,106,107]$, and so genotypic variations in non-coding regions must also be considered. Multilocus sequence typing and deep amplicon sequencing will be critical for better understanding the pathogenicity of certain strains and their ability to invade the human brain. Since spirochetes can deposit in the human brain and B. burgdorferi ss DNA can be identified in brain cells, we propose that next-generation sequencing is crucial to genotype the infectious spirochetes from human CSF and post-mortem LNB brain samples.

Second, the question remains whether post-treatment LNB results from a downstream host immune response or whether additional pathways are disrupted from spirochete penetrance into the brain. We believe that an in-depth study of acute vs. posttreatment Lyme disease profiling of antibody, chemokine, and cytokine response pathways is a critical first step to address this complicated question. One of the major limitations for this approach is the lack of appropriate animal models for LNB studies, although a recently developed murine model may offer an accessible option [135]. This mouse model exhibited an increase in the interferon response pathway in the cortex and hippocampus in acute, but not long-term, infection [135]. Interestingly, post-treatment LNB human serum retained elevated interferon levels $[175,176]$. These mouse and human studies suggest that interferon signaling may play an important role in post-treatment LNB and indeed, could possibly influence the long-term psychiatric symptoms [176]. This begs the question whether additional pathways are also disrupted during long-term LNB infection.

Third, better clinical diagnostic tests for detection of early stages of Lyme disease and better therapeutic treatments for patients affected by PTLDS are needed. Understanding the mechanisms and processes involved with why some patients fully recover and others develop long-term symptoms will be beneficial in addressing these needs. Some recent 
research suggests that small fiber neuropathy may be associated with PTLDS and might serve as a useful biomarker for evaluating PTLDS in patients [177].

Borrelia burgdorferi ss spirochetes regulate Osp expression based on its anatomical location in reservoir hosts and vectors. Therefore, this demands study of LNB in brain tissues, fluids, and cells, as B. burgdorferi ss gene expression differs between CSF and blood/skin $[74,178,179]$. Due to the limitations of accessing tissue from human patients, we propose that LNB is best studied using a mixture of human CSF and post-mortem tissue, in vivo animal infection using murine and non-human primates, and human primary brain cell cultures. There is likely a difference in infectivity of strains and genotypes across hosts, and so any mechanistic studies found in murine or non-human primate models will need to be verified in humans. Nonetheless, we believe that infectious strain specificity can be identified in patient tissues and long-term mechanistic studies can be carried out in laboratory animals. Combined, these works have the potential to influence clinical intervention of the currently untreatable and incurable symptoms of post-treatment LNB. Additionally, prevention of disease is an equally important component to address Lyme disease in public health. By surveilling natural B. burgdorferi ss infection in reservoir hosts and tick vectors, we can begin to identify locations with high human health risks of contracting neuroinvasive Lyme disease in North America.

Author Contributions: L.F. and D.M.T. were involved in conceptualization, investigation, writingoriginal draft preparation and review and editing, and visualization. D.M.T. was involved in supervision, project administration, and funding acquisition. All authors have read and agreed to the published version of the manuscript.

Funding: Funding for this review was provided by the University of Pittsburgh.

Conflicts of Interest: The authors declare no conflict of interest.

\section{References}

1. Van den Wijngaard, C.C.; Hofhuis, A.; Simões, M.; Rood, E.; Van Pelt, W.; Zeller, H.; Van Bortel, B. Surveillance perspective on Lyme borreliosis across the European Union and European economic area. Eurosurveillance 2017, 22, 30569. [CrossRef] [PubMed]

2. Cairns, V.; Wallenhorst, C.; Rietbrock, S.; Martinez, C. Incidence of Lyme disease in the UK: A population-based cohort study. BMJ Open 2019, 9, e025916. [CrossRef] [PubMed]

3. Kugeler, K.J.; Schwartz, A.M.; Delorey, M. Estimating the frequency of Lyme disease diagnoses—United States, 2010-2018. Emerg. Infect. Dis. 2021, 27, 616-619. [CrossRef] [PubMed]

4. Schwartz, A.M.; Kugeler, K.J.; Nelson, C.A. Use of commercial claims data for evaluating trends in Lyme disease diagnoses, United States, 2010-2018. Emerg. Infect. Dis. 2021, 27, 499-507. [CrossRef] [PubMed]

5. Radolf, J.D.; Caimano, M.J.; Stevenson, B.; Hu, L.T. Of ticks, mice and men: Understanding the dual-host lifestyle of Lyme disease spirochaetes. Nat. Rev. Microbiol. 2012, 10, 87-99. [CrossRef]

6. Centers for Disease Control and Prevention. National Center for Emerging and Zoonotic Infectious Diseases (NCEZID), Division of Vector-Borne Diseases (DVBD). Available online: www.cdc.gov (accessed on 28 May 2021).

7. Smith, R.P.; Schoen, R.T.; Rahn, D.W.; Sikand, V.K.; Nowakowski, J.; Parenti, D.L.; Holman, M.S.; Persing, D.H. Clinical characteristics and treatment outcome of early Lyme disease in patients with microbiologically confirmed erythema migrans. Ann. Intern. Med. 2002, 136, 421-428. [CrossRef]

8. Hengge, U.R.; Tannapfel, A.; Tyring, S.K.; Erbel, R.; Arendt, G.; Ruzicka, T. Lyme borreliosis. Lancet Infect. Dis. 2003, 3, 489-500. [CrossRef]

9. Wormser, G.P. Early Lyme disease. N. Engl. J. Med. 2006, 354, 2794-2801. [CrossRef]

10. Steere, A.C.; Strle, F.; Wormser, G.P.; Hu, L.T.; Branda, J.A.; Hovius, J.W.; Li, X.; Mead, P.S. Lyme borreliosis. Nat. Rev. Dis. Primers 2016, 2, 1-19. [CrossRef]

11. Logigian, E.L.; Kaplan, R.F.; Steere, A.C. Chronic neurologic manifestations of Lyme disease. N. Engl. J. Med. 1990, 323, 1438-1444. [CrossRef] [PubMed]

12. Stanek, G.; Wormser, G.P.; Gray, J.; Strle, F. Lyme borreliosis. Lancet 2012, 379, 461-473. [CrossRef]

13. Cardenas-de la Garza, J.A.; De la Cruz-Valadez, E.; Ocampo-Candiani, J.; Welsh, O. Clinical spectrum of Lyme disease. Eur. J. Clin. Microbiol. Infect. Dis. 2019, 38, 201-208. [CrossRef]

14. Radolf, J.D.; Strle, K.; Lemieux, J.E.; Strle, F. Lyme Disease in Humans. Curr. Issues Mol. Biol. 2021, 42, $333-384$.

15. Garin, C.; Bujadoux, A. Paralysis by Ticks. Clin. Infect. Dis. 1993, 16, 168-169. [CrossRef]

16. Pachner, A.R.; Steere, A.C. The triad of neurologic manifestations of Lyme disease: Meningitis, cranial neuritis, and radiculoneuritis. Neurology 1984, 35, 47-53. [CrossRef] [PubMed] 
17. Knudtzen, F.C.; Andersen, N.S.; Jensen, T.G.; Skarphedinsson, S. Characteristics and clinical outcome of Lyme Neuroborreliosis in a high endemic area, 1995-2014: A retrospective cohort study in Denmark. Clin. Infect. Dis. 2017, 65, 1489-1495. [CrossRef]

18. Halperin, J.J.; Shapiro, E.D.; Logigian, E.; Belman, A.L.; Dotevall, L.; Wormser, G.P.; Krupp, L.; Gronseth, G.; Bever, C.T. Practice parameter: Treatment of nervous system Lyme disease (an evidence-based review): Report of the Quality Standards Subcommittee of the American Academy of Neurology. Neurology 2007, 69, 91-102. [CrossRef] [PubMed]

19. Kristoferitsch, W. Neurological manifestations of Lyme borreliosis. Infection 1991, 19, 268-272. [CrossRef] [PubMed]

20. Kruger, H.; Reuss, K.; Pulz, M.; Rohrbach, E.; Pflughaupt, K.W.; Martin, R.; Mertens, H.G. Meningoradiculitis and encephalomyelitis due to Borrelia burgdorferi: A follow-up study of 72 patients over 27 years. J. Neurol. 1989, 236, 322-328. [CrossRef]

21. Van Dam, A.P.; Kuiper, H.; Vos, K.; Widjojokusumo, A.; De Jongh, B.M.; Spanjaard, L.; Ramselaar, A.C.; Kramer, M.D.; Dankert, J. Different genospecies of Borrelia burgdorferi are associated with distinct clinical manifestations of Lyme borreliosis. Clin. Infect. Dis. 1993, 17, 708-717. [CrossRef]

22. Wilske, B. Epidemiology and diagnosis of Lyme borreliosis. Ann. Med. 2005, 37, 568-579. [CrossRef] [PubMed]

23. Brisson, D.; Drecktrah, D.; Eggers, C.H.; Samuels, D.S. Genetics of Borrelia burgdorferi. Ann. Rev. Genet. 2012, 46, 515-536. [CrossRef] [PubMed]

24. Cerar, T.; Strle, F.; Stupica, D.; Ruzic-Sabljic, E.; McHugh, G.; Steere, A.C.; Strle, K. Differences in genotype, clinical features, and inflammatory potential of Borrelia burgdorferi sensu stricto strains from Europe and the United States. Emerg. Infect. Dis. 2016, $22,818$. [CrossRef] [PubMed]

25. Reik, L.; Steere, A.C.; Bartenhagen, N.H.; Shope, R.E.; Malawista, S.E. Neurologic abnormalities of Lyme disease. Medicine 1979, 58, 281-294. [CrossRef]

26. Koedel, U.; Fingerle, V.; Pfister, H.W. Lyme neuroborreliosis—Epidemiology, diagnosis and management. Nat. Rev. Neurol. 2015, 11, 446-456. [CrossRef]

27. DeLong, A.; Hsu, M.; Kotsoris, H. Estimation of cumulative number of post-treatment Lyme disease cases in the US, 2016 and 2020. BMC Public Health 2019, 19, 352. [CrossRef]

28. Shah, A.; O'Horo, J.C.; Wilson, J.W.; Granger, D.; Theel, E.S. An unusual cluster of neuroinvasive Lyme disease cases presenting with Bannwarth Syndrome in the Midwest United States. Open Forum Infect. Dis. 2017, 5, ofx276. [CrossRef] [PubMed]

29. Eddens, T.; Kaplan, D.J.; Anderson, A.J.; Nowalk, A.J.; Campfield, B.T. Insights from the geographic spread of the Lyme Disease epidemic. Clin. Infect. Dis. 2019, 68, 426-434. [CrossRef]

30. Morrissette, M.; Pitt, N.; Gonzalez, A.; Strandwitz, P.; Caboni, M.; Rebman, A.W.; Knight, R.; D’Onofrio, A.; Aucott, J.N.; Soloski, M.J.; et al. A distinct microbiome signature in posttreatment Lyme disease patients. MBio 2020, 11, e02310-20. [CrossRef]

31. Kan, L.; Sood, S.K.; Maytal, J. Pseudotumore cerebri in Lyme disease: A case report and literature review. Pediatr. Neurol. 1998, 18, 439-441. [CrossRef]

32. Steenhoff, A.P.; Smith, M.J.; Shah, S.S.; Coffin, S.E. Neuroborreliosis with progression from pseudotumore cerebri to aseptic meningitis. Pediatr. Infect. Dis. 2006, 25, 91-92. [CrossRef]

33. Moses, J.M.; Riseberg, R.S.; Mansbach, J.M. Lyme disease presenting with persistent headache. Pediatrics 2003, 112, e466-e479. [CrossRef]

34. Ewers, E.C.; Dennison, D.H.; Stagliano, D.R. A unique case of adolescent neuroborreliosis presenting with multiple cranial neuritis and cochlear inflammation on magnetic resonance imaging. Pediatr. Neurol. 2015, 52, 107-109. [CrossRef]

35. Walker, A.R.; Morales-Yurick, T. A noteworthy case report of neuroborreliosis in an unvaccinated pediatric patient. Clin. Pract. Cases Emerg. Med. 2020, 4, 671-674. [CrossRef]

36. Ramgopal, S.; Obeid, R.; Zuccoli, G.; Cleves-Bayon, C.; Nowalk, A. Lyme disease-related intracranial hypertension in children: Clinical and imaging findings. J. Neurol. 2016, 263, 500-507. [CrossRef]

37. Bransfield, R.C.; Aidlen, D.M.; Cook, M.J.; Javia, S. A clinical diagnostic system for late-stage neuropsychiatric Lyme Borreliosis based upon an analysis of 100 patients. Healthcare 2020, 8, 13. [CrossRef]

38. Halperin, J.J. Chronic Lyme disease: Misconceptions and challenges for patient management. Infect. Drug. Resist. 2015, 8, 119-128. [CrossRef]

39. Garcia-Monco, J.C.; Benach, J.L. Lyme Neuroborreliosis: Clinical outcomes, controversy, pathogenesis, and polymicrobial infections. Ann. Neurol. 2019, 85, 21-31. [CrossRef]

40. Henriksson, A.; Link, H.; Cruz, M.; Stiernstedt, G. Immunoglobulin abnormalities in cerebrospinal fluid and blood over the course of lymphocytic meningoradiculitis (Bannwarth's syndrome). Ann. Neurol. 1986, 20, 337-345. [CrossRef]

41. Kalish, R.A.; McHugh, G.; Granquist, J.; Shea, B.; Ruthazer, R.; Steere, A.C. Persistence of immunoglobulin M or immunoglobulin G antibody responses to Borrelia burgdorferi 10-20 years after active Lyme disease. Clin. Infect. Dis. 2001, 33, 780-785. [CrossRef]

42. Hurley, R.A.; Taber, K.H. Acute and chronic Lyme disease: Controversies for neuropsychiatry. J. Neuropsychiatry Clin. Neurosci. 2008, 20, iv-6. [CrossRef]

43. Newberg, A.; Hassan, A.; Alavi, A. Cerebral metabolic changes associated with Lyme disease. Nucl. Med. Commun. 2002, 23, 773-777. [CrossRef] [PubMed]

44. Paparone, P.W. Neuropsychiatric manifestations of Lyme disease. J. Am. Osteopath. Assoc. 1998, 98, 373-378. [PubMed]

45. Krupp, L.B.; Hyman, L.G.; Grimson, R.; Coyle, P.K.; Melville, P.; Ahnn, S.; Dattwyler, R.; Chandler, B. Study and treatment of post Lyme disease (STOP-LD): A randomized double masked clinical trial. Neurology 2003, 60, 1923-1930. [CrossRef] [PubMed] 
46. Klempner, M.S.; Baker, P.J.; Shapiro, E.D.; Marques, A.; Dattwyler, R.J.; Halperin, J.J.; Wormser, G.P. Treatment trials for post-Lyme Disease symptoms revisited. Am. J. Med. 2014, 126, 665-669. [CrossRef]

47. Ljostad, U.; Mygland, A. Remaining complaints 1 year after treatment for acute Lyme neuroborreliosis; frequency, pattern and risk factors. Eur. J. Neurol. 2010, 17, 118-123. [CrossRef] [PubMed]

48. Sharma, B.; Brown, A.V.; Matluck, N.E.; Hu, L.T.; Lewis, K. Borrelia burgdorferi, the causative agent of Lyme disease, forms drug-tolerant persister cells. Antimicrob. Agents Chem. 2015, 59, 4616-4624. [CrossRef]

49. Ogrinc, K.; Lusa, L.; Lotric-Furlan, S.; Bogovic, P.; Stupica, D.; Cerar, T.; Ruzic-Sabljic, E.; Strle, F. Course and outcome of early European Lyme neuroborreliosis (Bannwarth syndrome): Clinical and laboratory findings. Rev. Infect. Dis. 2016, 63, $346-353$. [CrossRef]

50. Eikeland, R.; Ljostad, U.; Helgeland, G.; Sand, G.; Flemmen, H.O.; Bo, M.H.; Nordaa, L.; Owe, J.F.; Mygland, A.; Lorentzen, A.R. Patient-reported outcome after treatment for definite Lyme neuroborreliosis. Brain Behav. 2020, 10, e01595. [CrossRef]

51. Nordberg, C.L.; Bodilsen, J.; Knudtzen, F.C.; Storgaard, M.; Brandt, C.; Wiese, L.; Hansen, B.R.; Andersen, A.B.; Nielsen, H.; Lebech, A.-M.; et al. Lyme neuroborreliosis in adults: A nationwide prospective cohort study. Ticks Tick Borne Dis 2020, 11, 101411. [CrossRef]

52. Liang, F.T.; Yan, J.; Mbow, M.L.; Sviat, S.L.; Gilmore, R.D.; Mamula, M.; Fikrig, E. Borrelia burgdorferi changes its surface antigenic expression in response to host immune responses. Infect. Immun. 2004, 72, 5759-5767. [CrossRef] [PubMed]

53. Kurtenbach, K.; Hanincova, K.; Tsao, J.I.; Margos, G.; Fish, D.; Ogden, N.H. Fundamental processes in the evolutionary ecology of Lyme borreliosis. Nat. Rev. Microbiol. 2006, 4, 660-669. [CrossRef]

54. Mather, T.N.; Wilson, M.L.; Moore, S.I.; Ribeiro, J.M.C.; Spielman, A. Comparing the relative potential of rodents as reservoirs of the Lyme disease spirochete (Borrelia burgdorferi). Am. J. Epidemiol. 1989, 130, 143-150. [CrossRef] [PubMed]

55. Telford, S.R., III; Mather, T.N.; Adler, G.H.; Spielman, A. Short-tailed shrews as reservoirs of the agents of Lyme disease and human babesiosis. J. Parasitol. 1990, 76, 681-683. [PubMed]

56. Levin, M.; Levine, J.F.; Apperson, C.S.; Norris, D.E.; Howard, P.B. Reservoir competence of the rice rat (Rodentia: Cricetidae) for Borrelia burgdorferi. J. Med. Entomol. 1995, 32, 138-142. [CrossRef] [PubMed]

57. Markowski, D.; Ginsberg, H.S.; Hyland, K.E.; Hu, R. Reservoir competence of the meadow vole (Rodentia: Cricetidae) for the Lyme disease spirochete Borrelia burgdorferi. J. Med. Entomol. 1998, 35, 804-808. [CrossRef]

58. Richter, D.; Spielman, A.; Komar, N.; Matuschka, F.R. Competence of American robins as reservoir hosts for Lyme disease spirochetes. Emerg. Infect. Dis. 2000, 6, 133-138. [CrossRef]

59. Brisson, D.; Dykhuizen, D.E. ospC diversity in Borrelia burgdorferi: Different hosts are different niches. Genetics 2004, 168, 713-722. [CrossRef]

60. Ginsberg, H.S.; Buckley, P.A.; Balmforth, M.G.; Zhioua, E.; Mitra, S.; Buckley, F.G. Reservoir competence of native North American birds for the Lyme disease spirochete, Borrelia burgdorferi. J. Med. Entomol. 2005, 42, 445-449. [CrossRef] [PubMed]

61. Lane, R.S.; Mun, J.; Eisen, R.J.; Eisen, L. Western gray squirrel (Rodentia: Sciuridae): A primary reservoir host of Borrelia burgdorferi in Californian oak woodlands? J. Med. Entomol. 2005, 42, 388-396. [CrossRef]

62. Hamer, S.A.; Hickling, G.J.; Sidge, J.L.; Rosen, M.E.; Walker, E.D.; Tsao, J.I. Diverse Borrelia burgdorferi strains in a bird-tick cryptic cycle. Appl. Environ. Microbiol. 2011, 77, 1999-2007. [CrossRef]

63. Hersh, M.H.; Ostfeld, R.S.; McHenry, D.J.; Tibbetts, M.; Brunner, J.L.; Killilea, M.E.; LoGiudice, K.; Schmidt, K.A.; Keesing, F. Co-infection of blacklegged ticks with Babesia microti and Borrelia burgdorferi is higher than expected and acquired from small mammal hosts. PLoS ONE 2014, 9, e99348. [CrossRef]

64. Vuong, H.B.; Canham, C.D.; Fonseca, D.M.; Brisson, D.; Morin, P.J.; Smouse, P.E.; Ostfeld, R.S. Occurrence and transmission efficiencies of Borrelia burgdorferi ospC types in avian and mammalian wildlife. Infect. Genet. Evol. 2014, 27, 594-600. [CrossRef] [PubMed]

65. Tufts, D.M.; Hart, T.M.; Chen, G.F.; Kolokotronis, S.-O.; Diuk-Wasser, M.A.; Lin, Y.-P. Outer surface protein polymorphisms linked to host-spirochete association in Lyme borreliae. Mol. Microbiol. 2019, 111, 868-882. [CrossRef] [PubMed]

66. Tracy, K.E.; Baumgarth, N. Borrelia burgdorferi manipulates innate and adaptive immunity to establish persistence in rodent reservoir hosts. Front. Immunol. 2017, 8, 116. [CrossRef]

67. Piesman, J. Dynamics of Borrelia burgdorferi transmission by nymphal Ixodes dammini ticks. J. Infect. Dis. 1993, 167, 1082-1085. [CrossRef]

68. Peavey, C.A.; Lane, R.S. Transmission of Borrelia burgdorferi by Ixodes pacificus nymphs and reservoir competence of deer mice (Peromyscus maniculatus) infected by tick-bite. J. Parasitol. 1995, 81, 175-178. [CrossRef] [PubMed]

69. Crippa, M.; Rais, O.; Gern, L. Investigations on the mode and dynamics of transmission and infectivity of Borrelia burgdorferi sensu stricto and Borrelia afzelii in Ixodes ricinus ticks. Vector Borne Zoonot. Dis. 2002, 2, 3-9. [CrossRef] [PubMed]

70. Yang, X.F.; Pal, U.; Alani, S.M.; Fikrig, E.; Norgard, M.V. Essential role for OspA/B in the life cycle of the Lyme disease spirochete. J. Exp. Med. 2004, 199, 641-648. [CrossRef]

71. Neelakanta, G.; Li, X.; Pal, U.; Liu, X.; Beck, D.S.; DePonte, K.; Fish, D.; Kantor, F.S.; Fikrig, E. Outer surface protein B is critical for Borrelia burgdorferi adherence and survival within Ixodes ticks. PLoS Pathog. 2007, 3, e33. [CrossRef]

72. Pal, U.; Li, X.; Wang, T.; Montgomery, R.R.; Ramamoorthi, N.; DeSilva, A.M.; Bao, F.; Yang, X.; Pypaert, M.; Pradhan, D.; et al. TROSPA, an Ixodes scapularis receptor for Borrelia burgdorferi. Cell 2004, 119, 457-468. [CrossRef] 
73. Caimano, M.J.; Drecktrah, D.; Kung, F.; Samuels, D.S. Interaction of the Lyme disease spirochete with its tick vector. Cell. Microbiol. 2016, 18, 919-927. [CrossRef] [PubMed]

74. Hyde, J.A. Borrelia burgdorferi keeps moving and carries on: A review of Borrelial dissemination and invasion. Front. Immunol. 2017, 8, 114. [CrossRef] [PubMed]

75. Hubner, A.; Yang, X.; Nolen, D.M.; Popova, T.G.; Cabello, F.C.; Norgard, M.V. Expression of Borrelia burgdorferi OspC and DbpA is controlled by a RpoN-RpoS regulatory pathway. Proc. Natl. Acad. Sci. USA 2001, 98, 12724-12729. [CrossRef] [PubMed]

76. Srivastava, S.Y.; De Silva, A.M. Reciprocal expression of ospA and ospC in single cells of Borrelia burgdorferi. J. Bacteriol. 2008, 190, 3429. [CrossRef] [PubMed]

77. Carrasco, S.E.; Yang, Y.; Troxell, B.; Yang, X.; Pal, U.; Yang, X.F. Borrelia burgdorferi elongation factor EF-Tu is an immunogenic protein during Lyme borreliosis. Emerg. Microbes Infect. 2015, 4, e54. [CrossRef] [PubMed]

78. Liang, F.T.; Jacobs, M.B.; Bowers, L.C.; Philipp, M.T. An immune evasion mechanism for spirochetal persistence in Lyme borreliosis. J. Exp. Med. 2002, 195, 415-422. [CrossRef] [PubMed]

79. Grimm, D.; Eggers, C.H.; Caimano, M.J.; Tilly, K.; Stewart, P.E.; Elias, A.F.; Radolf, J.D.; Rosa, P. A Experimental assessment of the roles of linear plasmids lp25 and lp28-1 of Borrelia burgdorferi throughout the infectious cycle. Infect. Immun. 2004, 72, 5938. [CrossRef] [PubMed]

80. Pal, U.; Yang, X.; Chen, M.; Bockenstedt, L.K.; Anderson, J.F.; Flavell, R.A.; Norgard, M.V.; Fikrig, E. OspC facilitates Borrelia burgdorferi invasion of Ixodes scapularis salivary glands. J. Clin. Invest. 2004, 113, 220-230. [CrossRef]

81. Tilly, K.; Krum, J.G.; Bestor, A.; Jewett, M.W.; Grimm, D.; Bueschel, D.; Byram, R.; Dorward, D.; VanRaden, M.J.; Stewart, P.; et al. Borrelia burgdorferi OspC protein required exclusively in a crucial early stage of mammalian infection. Infect. Immun. 2006, 74, 3554-3564. [CrossRef]

82. Xu, Q.; McShan, K.; Liang, F.T. Essential protective role attributed to the surface lipoproteins of Borrelia burgdorferi against innate defences. Mol. Microbiol. 2008, 69, 15-29. [CrossRef]

83. Gilmore, R.D.; Kappel, K.J.; Dolan, M.C.; Burkot, T.R.; Johnson, B.J. Outer surface protein C (OspC), but not P39, is a protective immunogen against a tick-transmitted Borrelia burgdorferi challenge: Evidence for a conformational protective epitope in OspC. Infect. Immun. 1996, 64, 2234-2239. [CrossRef]

84. Zeidner, N.S.; Schneider, B.S.; Nuncio, M.S.; Gern, L.; Piesman, J. Coinoculation of Borrelia spp. with tick salivary gland lysate enhances spirochete load in mice and is tick species-specific. J. Parasitol. 2002, 88, 1276-1278. [PubMed]

85. Anguita, J.; Hedrick, M.N.; Fikrig, E. Adaptation of Borrelia burgdorferi in the tick and the mammalian host. FEMS Microbiol. Rev. 2003, 27, 493-504. [CrossRef]

86. Schuijt, T.J.; Hovius, J.W.; Van Burgel, N.D.; Ramamoorthi, N.; Fikrig, E.; Van Dam, A.P. The tick salivary protein Salp15 inhibits the killing of serum-sensitive Borrelia burgdorferi sensu lato isolates. Infect. Immun. 2008, 76, 2888-2894. [CrossRef] [PubMed]

87. Guo, X.; Booth, C.J.; Paley, M.A.; Wang, X.; DePonte, K.; Fikrig, E.; Narasimhan, S.; Montgomery, R.R. Inhibition of neutrophil function by two tick salivary proteins. Infect. Immun. 2009, 77, 2320-2329. [CrossRef]

88. Mason, L.M.; Veerman, C.C.; Geijtenbeek, T.B.; Hovius, J.W. Menage a trois: Borrelia, dendritic cells, and tick saliva interactions. Trends Parasitol. 2014, 30, 95-103. [CrossRef]

89. Seinost, G.; Dykhuizen, D.E.; Dattwyler, R.J.; Golde, W.T.; Dunn, J.J.; Wang, I.N.; Wormser, G.P.; Schriefer, M.E.; Luft, B.J. Four clones of Borrelia burgdorferi sensu stricto cause invasive infection in humans. Infect. Immun. 1999, 67, 3518-3524. [CrossRef]

90. Wormser, G.P.; Brisson, D.; Liveris, D.; Hanincova, K.; Sandigursky, S.; Nowakowski, J.; Nadelman, R.B.; Ludin, S.; Schwartz, I. Borrelia burgdorferi genotype predicts the capacity for hematogenous dissemination during early Lyme disease. J. Infect. Dis. 2008, 198, 1358-1364. [CrossRef]

91. Barbour, A.G.; Bunikis, J.; Travinsky, B.; Hoen, A.G.; Diuk-Wasser, M.A.; Fish, D.; Tsao, J.I. Niche partitioning of Borrelia burgdorferi and Borrelia miyamotoi in the same tick vector and mammalian reservoir species. Am. J. Trop. Med. Hyg. 2009, 81, $1120-1131$. [CrossRef]

92. Mechai, S.; Margos, G.; Feil, E.J.; Barairo, N.; Lindsay, L.R.; Michel, P.; Ogden, N.H. Evidence for host-genotype associations of Borrelia burgdorferi sensu stricto. PLoS ONE 2016, 11, e0149345. [CrossRef]

93. Wang, G.; Ojaimi, C.; Wu, H.; Saksenberg, V.; Iyer, R.; Liveris, D.; McClain, S.A.; Wormser, G.P.; Schwartz, I. Disease severity in a murine model of Lyme borreliosis is associated with the genotype of the infecting Borrelia burgdorferi sensu stricto strain. J. Infect. Dis. 2002, 186, 782-791. [CrossRef] [PubMed]

94. Earnhart, C.G.; Buckles, E.L.; Dumler, J.S.; Marconi, R.T. Demonstration of OspC type diversity in invasive human Lyme disease isolates and identification of previously uncharacterized epitopes that define the specificity of the OspC murine antibody response. Infect. Immun. 2005, 73, 7869. [CrossRef] [PubMed]

95. Brisson, D.; Dykhuizen, D.E. A modest model explains the distribution and abundance of Borrelia burgdorferi strains. Am. J. Trop. Med. Hyg. 2006, 74, 615-622. [CrossRef]

96. Dykhuizen, D.E.; Brisson, D.; Sandigursky, S.; Wormser, G.P.; Nowakowski, J.; Nadelman, R.B.; Schwartz, I. The propensity of different Borrelia burgdorferi sensu stricto genotypes to cause disseminated infections in humans. Am. J. Trop. Med. Hyg. 2008, 78, 806-810. [CrossRef]

97. Brisson, D.; Baxamusa, N.; Schwartz, I.; Wormser, G.P. Biodiversity of Borrelia burgdorferi strains in tissues of Lyme disease patients. PLoS ONE 2011, 6, e22926. [CrossRef] 
98. Hanincova, K.; Mukherjee, P.; Ogden, N.H.; Margos, G.; Wormser, G.P.; Reed, K.D.; Meece, J.K.; Vandermause, M.F.; Schwartz, I. Multilocus sequence typing of Borrelia burgdorferi suggests existence of lineages with differential pathogenic properties in humans. PLoS ONE 2013, 8, e73066. [CrossRef] [PubMed]

99. Coipan, E.C.; Jahfari, S.; Fonville, M.; Oei, G.A.; Spanjaard, L.; Takumi, K.; Hovius, J.W.R.; Sprong, H. Imbalanced presence of Borrelia burgdorferi sl multilocus sequence types in clinical manifestations of Lyme borreliosis. Infect. Genet. Evol. 2016, $42,66-76$. [CrossRef]

100. Liveris, D.; Wormser, G.P.; Nowakowski, J.; Nadelman, R.; Bittker, S.; Cooper, D.; Varde, S.; Moy, F.H.; Forseter, G.; Pavia, C.S.; et al. Molecular typing of Borrelia burgdorferi from Lyme disease patients by PCR-restriction fragment length polymorphism analysis. J. Clin. Microbiol. 1996, 34, 1306. [CrossRef]

101. Peavey, C.A.; Lane, R.S. Comparison of infectivities of six tick-derived isolates of Borrelia burgdorferi for rodents and ticks. J. Clin. Microbiol. 1996, 34, 71. [CrossRef]

102. Baranton, G.; Seinost, G.; Theodore, G.; Postic, D.; Dykhuizen, D. Distinct levels of genetic diversity of Borrelia burgdorferi are associated with different aspects of pathogenicity. Res. Microbiol. 2001, 152, 149-156. [CrossRef]

103. Thomas, V.; Anguita, J.; Barthold, S.W.; Fikrig, E. Coinfection with Borrelia burgdorferi and the agent of human granulocytic ehrlichiosis alters murine immune responses, pathogen burden, and severity of Lyme arthritis. Infect. Immun. 2001, 69, 3359. [CrossRef]

104. Xiang, X.; Yang, Y.; Du, J.; Lin, T.; Chen, T.; Yang, X.F.; Lou, Y. Investigation of ospC expression variation among Borrelia burgdorferi strains. Front. Cell. Infect. Microbiol. 2017, 7, 131. [CrossRef] [PubMed]

105. Bunikis, J.; Garpmo, U.; Tsao, J.; Berglund, J.; Fish, D.; Barbour, A.G. Sequence typing reveals extensive strain diversity of the Lyme borreliosis agents Borrelia burgdorferi in North America and Borrelia afzelii in Europe. Microbiology 2004, 150, $1741-1755$. [CrossRef] [PubMed]

106. Travinsky, B.; Bunikis, J.; Barbour, A.G. Geographic differences in genetic locus linkages for Borrelia burgdorferi. Emerg. Infect. Dis. 2010, 16, 1147-1150. [CrossRef]

107. Ogden, N.H.; Margos, G.; Aanensen, D.M.; Drebot, M.A.; Feil, E.J.; Hanincova, K.; Schwartz, I.; Tyler, S.; Lindsay, L.R. Investigation of genotypes of Borrelia burgdorferi in Ixodes scapularis ticks collected during surveillance in Canada. Appl. Environ. Microbiol. 2011, 77, 3244. [CrossRef]

108. States, S.L.; Brinkerhoff, R.J.; Carpi, G.; Steeves, T.K.; Folsom-O’Keefe, C.; DeVeaux, M.; Diuk-Wasser, M.A. Lyme disease risk not amplified in a species-poor vertebrate community: Similar Borrelia burgdorferi tick infection prevalence and OspC genotype frequencies. Infect. Genet. Evol. 2014, 27, 566-575. [CrossRef]

109. Di, L.; Wan, Z.; Akther, S.; Ying, C.; Larracuente, A.; Li, L.; Di, C.; Nunez, R.; Cucura, D.M.; Goddard, N.L.; et al. Genotyping and quantifying Lyme pathogen strains by deep sequencing of the outer surface protein C (ospC) locus. J. Clin. Microbiol. 2018, 56, e00940-18. [CrossRef]

110. Rynkiewicz, E.C.; Brown, J.; Tufts, D.M.; Huang, C.I.; Kampen, H.; Bent, S.J.; Fish, D.; Diuk-Wassler, M.A. Closely-related Borrelia burgdorferi (sensu stricto) strains exhibit similar fitness in single infections and asymmetric competition in multiple infections. Parasites Vectors 2017, 10, 64. [CrossRef]

111. States, S.L.; Huang, C.I.; Davis, S.; Tufts, D.M.; Diuk-Wasser, M.A. Co-feeding transmission facilitates strain coexistence in Borrelia burgdorferi, the Lyme disease agent. Epidemics 2017, 19, 33-42. [CrossRef] [PubMed]

112. Adelson, M.E.; Rao, R.V.S.; Tilton, R.C.; Cabets, K.; Eskow, E.; Fein, L.; Occi, J.L.; Mordechai, E. Prevalence of Borrelia burgdorferi, Bartonella spp., Babesia microti, and Anaplasma phagocytophila in Ixodes scapularis ticks collected in Northern New Jersey. J. Clin. Microbiol. 2004, 42, 2799-2801. [CrossRef] [PubMed]

113. Johnson, T.L.; Graham, C.B.; Maes, S.E.; Hojgaard, A.; Fleshman, A.; Boegler, K.A.; Delory, M.J.; Slater, K.S.; Karpathy, S.E.; Bjork, J.K.; et al. Prevalence and distribution of seven human pathogens in host-seeking Ixodes scapularis (Acari: Ixodidae) nymphs in Minnesota, USA. Ticks Tick Borne Dis. 2018, 9, 1499-1507. [CrossRef] [PubMed]

114. Parveen, N.; Bhanot, P. Babesia microti-Borrelia burgdorferi coinfection. Pathogens 2019, 8, 117. [CrossRef]

115. Little, E.A.H.; Molaei, G. Passive tick surveillance: Exploring spatiotemporal associations of Borrelia burgdorferi, Babesia microti, and Anaplasma phagocytophilum infection in Ixodes scapularis. Vector Borne Zoonot. Dis. 2020, 20, 177-186. [CrossRef] [PubMed]

116. Lehane, A.; Maes, S.E.; Graham, C.B.; Jones, E.; Delorey, M.; Eisen, R.J. Prevalence of single and coinfections of human pathogens in Ixodes ticks from five geographical regions in the United States, 2013-2019. Ticks Tick Borne Dis. 2021, 12, 101637. [CrossRef]

117. Lin, Y.P.; Tufts, D.M.; Dupuis, A.P.; Combs, M.; Marcinkiewicz, A.L.; Hirsbrunner, A.D.; Diaz, A.J.; Stout, J.L.; Blom, A.M.; Strle, K.; et al. Host specialization in microparasites transmitted by generalist vectors: Insights into the cellular and immunological mechanisms. bioRxiv 2020. [CrossRef]

118. Seifert, S.N.; Khatchikian, C.E.; Zhou, W.; Brisson, B. Evolution and population genomics of the Lyme borreliosis pathogen, Borrelia burgdorferi. Trends Genet. 2016, 31, 201-207. [CrossRef]

119. Fraser, C.M.; Casjens, S.; Huang, W.M.; Sutton, G.G.; Clayton, R.; Lathigra, R.; White, O.; Ketchum, K.A.; Dodson, R.; Hickey, E.K.; et al. Genomic sequence of a Lyme disease spirochaete, Borrelia burgdorferi. Nature 1997, 390, 580-586. [CrossRef]

120. Casjens, S. Borrelia genomes in the year 2000. J. Molec. Microbiol. Biotechnol. 2000, 2, 401-410.

121. Casjens, S.R.; Fraser-Liggett, C.M.; Mongodin, E.F.; Qiu, W.G.; Dunn, J.J.; Luft, B.J.; Schutzer, S.E. Whole genome sequence of an unusual Borrelia burgdorferi sensu lato isolate. J. Bacteriol. 2011, 193, 1489-1490. [CrossRef] 
122. Schutzer, S.E.; Fraser-Liggett, C.M.; Casjens, S.R.; Qiu, W.G.; Dunn, J.J.; Mongodin, E.F.; Luft, B.L. Whole-genome sequences of thirteen isolates of Borrelia burgdorferi. J. Bacteriol. 2011, 193, 1018. [CrossRef] [PubMed]

123. Stewart, P.E.; Rosa, P.A. Physiologic and genetic factors influencing the zoonotic cycle of Borrelia burgdorferi. In Spirochete Biology: The Post Genomic Era; Alder, B., Ed.; Springer: Berlin/Heidelberg, Germany, 2017; pp. 63-82.

124. Purser, J.E.; Norris, S.J. Correlation between plasmid content and infectivity in Borrelia burgdorferi. Proc. Natl. Acad. Sci. USA 2000, 97, 13865-13870. [CrossRef] [PubMed]

125. Kraiczy, P.; Skerka, C.; Brade, V.; Zipfel, P.E. Further characterization of complement regulator-acquiring surface proteins of Borrelia burgdorferi. Infect. Immun. 2001, 69, 7800-7809. [CrossRef]

126. Hartmann, K.; Corvey, C.; Skerka, C.; Kirschfink, M.; Karas, M.; Brade, V.; Miller, J.C.; Stevenson, B.; Wallich, R.; Zipfel, P.F Functional characterization of BbCRASP-2, a distinct outer membrane protein of Borrelia burgdorferi that binds host complement regulators factor H and FHL-1. Mol. Microbiol. 2006, 61, 1220-1236. [CrossRef]

127. Bykowski, T.; Woodman, M.E.; Cooley, A.E.; Brissette, C.A.; Brade, V.; Wallich, R.; Kraiczy, P.; Stevenson, B. Coordinated expression of Borrelia burgdorferi complement regulator-acquiring surface proteins during the Lyme disease spirochete's mammaltick infection cycle. Infect. Immun. 2007, 75, 4227-4236. [CrossRef]

128. Kraiczy, P.; Stevenson, B. Complement regulator-acquiring surface proteins of Borrelia burgdorferi: Structure, function and regulation of gene expression. Ticks Tick Borne Dis. 2013, 4, 26-34. [CrossRef]

129. Bouquet, J.; Soloski, M.J.; Swei, A.; Cheadle, C.; Federman, S.; Billaud, J.N.; Rebman, A.W.; Kabre, B.; Halpert, R.; Boorgula, M.; et al. Longitudinal transcriptome analysis reveals a sustained differential gene expression signature in patients treated for acute Lyme disease. mBio 2016, 7, e00100-e00116. [CrossRef]

130. Hart, T.; Nguyen, N.T.T.; Nowak, N.A.; Zhang, F.; Linhardt, R.J.; Diuk-Wasser, M.; Ram, S.; Kraiczy, P.; Lin, Y.-P. Polymorphic factor H-binding activity of CspA protects Lyme borreliae from the host complement in feeding ticks to facilitate tick-to-host transmission. PLoS Pathog. 2018, 14, e1007106. [CrossRef]

131. Schutzer, S.E.; Coye, P.K.; Krupp, L.B.; Deng, Z.; Belman, A.L.; Dattwyler, R.; Luft, B.J. Simultaneous expression of Borellia OspA and OspC and IgM response in cerebrospinal fluid in early neurologic Lyme disease. J. Clin. Investig. 1997, 100, 763-767. [CrossRef] [PubMed]

132. Schutzer, S.E.; Angel, T.E.; Liu, T.; Schepmoes, A.A.; Clauss, T.R.; Adkins, J.N.; Camp, D.G.; Holland, B.K.; Bergquist, J.; Coyle, P.K.; et al. Distinct cerebrospinal fluid proteomes differentiate post-treatment Lyme disease from chronic fatigue syndrome. PLoS ONE 2011, 6, e17287. [CrossRef] [PubMed]

133. Pachner, A.R.; Delaney, E.; O'Neil, T.; Major, E. Inoculation of nonhuman primates with the N40 strain of Borrelia burgdorferi leads to a model of Lyme neuroborreliosis faithful to the human model. Neurology 1995, 45, 165-172. [CrossRef] [PubMed]

134. Divan, A.; Casselli, T.; Narayanan, S.A.; Mukherjee, S.; Zawieja, D.C.; Watt, J.A.; Brissette, C.A.; Newell-Rogers, M.K. Borrelia burgdorferi adhere to blood vessels in the dura mater and are associated with increased meningeal T cells during murine disseminated borreliosis. PLoS ONE 2018, 13, e0196893. [CrossRef] [PubMed]

135. Casselli, T.; Divan, A.; Vomhof-DeKrey, E.E.; Tourand, Y.; Pecoraro, H.L.; Brissette, C.A. A murine model of Lyme disease demonstrates that Borrelia burgdorferi colonizes the dura mater and induces inflammation in the central nervous system. PLoS Pathog 2021, 17, e1009256. [CrossRef] [PubMed]

136. Allal, J.; Thomas, P.; Mazzonelli, J. Borrelia isolated from cerebrospinal fluid in a French case of Lyme disease. Ann. Rheum. Dis. 1986, 45, 789. [CrossRef] [PubMed]

137. Luft, B.J.; Steinman, C.R.; Neimark, H.C.; Muralidhar, B.; Rush, T.; Finkel, M.F.; Kunkel, M.; Dattwyler, R.J. Invasion of the central nervous system by Borrelia burgdorferi in acute disseminated infection. JAMA 1992, 267, 1364-1367. [CrossRef]

138. Rupprecht, T.A.; Koedel, U.; Fingerle, V.; Pfister, H.W. The pathogenesis of Lyme neuroborreliosis: From infection to inflammation. Mol. Med. 2008, 14, 205-212. [CrossRef]

139. Fallon, B.A.; Levin, E.S.; Schweitzer, P.J.; Hardesty, D. Inflammation and central nervous system Lyme disease. Neurobiol. Dis. 2010, 37, 534-541. [CrossRef]

140. Zipfel, P.F.; Skerka, C. Complement regulators and inhibitory proteins. Nat. Rev. Immun. 2009, 9, 729-740. [CrossRef]

141. Ricklin, D.; Hajishengallis, G.; Yang, K.; Lambris, J.D. Complement: A key system for immune surveillance and homeostasis. Nat. Immun. 2010, 11, 785-797. [CrossRef]

142. Petzke, M.; Schwartz, I. Borrelia burgdorferi pathogenesis and the immune response. Clin. Lab. Med. 2015, 35, 745-764. [CrossRef]

143. Verhaegh, D.; Joosten, L.A.; Oosting, M. The role of host immune cells and Borrelia burgdorferi antigens in the etiology of Lyme disease. Eur. Cytokine Netw. 2017, 28, 70-84. [CrossRef]

144. Thompson, D.; Sorenson, J.; Greenmyer, J.; Brissette, C.A.; Watt, J.A. The Lyme disease bacterium, Borrelia burgdorferi, stimulates an inflammatory response in human choroid plexus epithelial cells. PLoS ONE 2020, 15, e0234993. [CrossRef]

145. Ding, Z.; Ma, M.; Tao, L.; Peng, Y.; Han, Y.; Sun, L.; Dai, X.; Ji, Z.; Bai, R.; Jian, M.; et al. Rhesus brain transcriptomic landscape in an ex vivo model of the interaction of live Borrelia burgdorferi with frontal cortex tissue explants. Front. Neurosci. $2019,13,651$. [CrossRef]

146. Ramesh, G.; Borda, J.T.; Dufour, J.; Kaushal, D.; Ramamoorthy, R.; Lackner, A.A.; Philipp, M.T. Interaction of the Lyme disease spirochete Borrelia burgdorferi with brain parenchyma elicits inflammatory mediators from glial cells as well as glial and neuronal apoptosis. Am. J. Pathol. 2008, 173, 1415-1427. [CrossRef] 
147. Ramesh, G.; Borda, J.T.; Gill, A.; Ribka, E.P.; Morici, L.A.; Mottram, P.; Martin, D.S.; Jacobs, M.B.; Didier, P.J.; Philipp, M.T. Possible role of glial cells in the onset and progression of Lyme neuroborreliosis. J. Neuroinflam. 2009, 6, 1-16. [CrossRef]

148. Parathasarathy, G.; Philipp, M.T. The MEK/ERK pathway is the primary conduit for Borrelia burgdorferi-induced inflammation and P53-mediated apoptosis in oligodendrocytes. Apoptosis 2014, 19, 76-89. [CrossRef]

149. Lantos, P.M. Chronic Lyme disease: The controversies and the science. Expert Rev. Anti-Infect. Ther. 2011, 9, 787-797. [CrossRef] [PubMed]

150. Maloney, E.L. Controversies in Persistent (Chronic) Lyme Disease. J. Infus. Nurs. 2016, 39, 369-375. [CrossRef] [PubMed]

151. Greenberg, R. Chronic Lyme Disease: An unresolved controversy. Am. J. Med. 2017, 130, e423. [CrossRef] [PubMed]

152. Gocko, X.; Tattevin, P.; Lemogne, C. Genesis and dissemination of a controversial disease: Chronic Lyme. Infect. Dis. Now 2021, 51, 86-89. [CrossRef] [PubMed]

153. Schmidt, S.; Denk, S.; Wiegering, A. Targeting protein synthesis in colorectal cancer. Cancers 2020, 12, 1298. [CrossRef] [PubMed]

154. Bilsborough, J.; Viney, J.L. GPR15: A tale of two species. Nat. Immunol. 2015, 16, 137-139. [CrossRef] [PubMed]

155. Rao, S.-Q.; Hu, H.-L.; Ye, N.; Shen, Y.; Xu, Q. Genetic variants in long non-coding RNA MIAT contribute to risk of paranoid schizophrenia in a Chinese Han population. Schizophr. Res. 2015, 166, 125-130. [CrossRef]

156. Casselli, T.; Qureshi, H.; Peterson, E.; Perley, D.; Blake, E.; Jokinen, B.; Abbas, A.; Nechaev, S.; Watt, J.A.; Dhasarathy, A.; et al. MicroRNA and mRNA transcriptome profiling in primary human astrocytes infected with Borrelia burgdorferi. PLoS ONE 2017, 12, e0170961. [CrossRef] [PubMed]

157. Garcia-Monco, J.C.; Fernandez-Villar, B.; Benach, J.L. Adherence of the Lyme disease spirochete to glial cells and cells of glial origin. J. Infect. Dis. 1989, 160, 497-506. [CrossRef] [PubMed]

158. Peters, D.J.; Benach, J.L. Borrelia burgdorferi adherence and injury to undifferentiated and differentiated neural cells in vitro. J. Infect. Dis. 1997, 176, 470-477. [CrossRef] [PubMed]

159. Pulzova, L.; Kovac, A.; Mucha, R.; Mlynarcik, P.; Bencurova, E.; Madar, M.; Novak, M.; Bhide, M. OspA-CD40 dyad: Ligandreceptor interaction in the translocation of neuroinvasive Borrelia across the blood-brain barrier. Sci. Rep. 2011, 1, 1-10. [CrossRef] [PubMed]

160. Kim, K.; Palmore, G.T.R. Lipoproteins and diseases of the brain. Adv Lipopro Res. Rijeka: InTech 2017, 95, 108.

161. Livengood, J.A.; Gilmore, R.D. Invasion of human neuronal glial cells by an infectious strain of Borrelia burgdorferi. Microbes Infect 2006, 8, 2832-2840. [CrossRef]

162. MacDonald, A.B.; Miranda, J.M. Concurrent neocortical borreliosis and Alzheimer's disease. Hum. Pathol. 1987, $18,759-761$. [CrossRef]

163. MacDonald, A.B. Borrelia in the brains of patients dying with dementia. JAMA 1986, 256, 2195-2196. [CrossRef] [PubMed]

164. Miklossy, J.; Khalili, K.; Gern, L.; Ericson, R.L.; Darekar, P.; Bolle, L.; Hurlimann, J.; Paster, B.J. Borrelia burgdorferi persists in the brain in chronic Lyme neuroborreliosis and may be associated with Alzheimers disease. J. Alzheimers Dis. 2004, 6, 639-649. [CrossRef] [PubMed]

165. MacDonald, A.B. Plaques of Alzheimer's disease originate from cysts of Borrelia burgdorferi, the Lyme disease spirochete. Med. Hypotheses 2006, 67, 592-600. [CrossRef] [PubMed]

166. Miklossy, J.; Kass, S.; Zurn, A.D.; McCall, S.; Yu, S.; McGreer, P.L. Persisting atypical and cystic forms of Borrelia burgdorferi and local inflammation in Lyme neuroborreliosis. J. Neuroinflam. 2008, 5, 1-18. [CrossRef] [PubMed]

167. Miklossy, J. Chronic or late Lyme neuroborreliosis: Analysis of evidence compared to chronic or late neurosyphilis. Open Neurol. J. 2012, 6, 146-157. [CrossRef] [PubMed]

168. Miklossy, J. Historic evidence to support a causal relationship between spirochetal infections and Alzheimer's disease. Front. Aging Neurosci. 2015, 7, 46. [CrossRef] [PubMed]

169. Sapi, E.; Kasliwala, R.S.; Ismail, H.; Torres, J.P.; Oldakowski, M.; Markland, S.; Gaur, G.; Melillo, A.; Eisendle, K.; Liegner, K.B.; et al. The long-term persistence of Borrelia burgdorferi antigens and DNA in the tissues of a patient with Lyme Disease. Antibiotics 2019, 8, 183. [CrossRef]

170. MacDonald, A.B. Alzheimer plaques visualized by in situ DNA hybridization with molecular beacons specific for Borrelia-a novel histomorphologic application. Med. Clin. Res. 2021, 6, 388-390.

171. Steere, A.C.; Grodzicki, R.L.; Kornblatt, A.N.; Craft, J.E.; Barbour, A.G.; Burgdorfer, W.; Schmid, G.P.; Johnson, E.; Malawista, S.E. The spirochetal etiology of Lyme disease. N. Engl. J. Med. 1983, 308, 733-740. [CrossRef]

172. Stevenson, B.; El-Hage, N.; Hines, M.A.; Miller, J.C.; Babb, K. Differential binding of host complement inhibitor factor H by Borrelia burgdorferi Erp surface proteins: A possible mechanism underlying the expansive host range of Lyme disease spirochetes. Infect. Immun. 2002, 70, 491-497. [CrossRef]

173. Miller, J.C.; Stevenson, B. Borrelia burgdorferi erp genes are expressed at different levels within tissues of chronically infected mammalian hosts. Int. J. Med. Microbiol. 2006, 40, 185-194. [CrossRef] [PubMed]

174. Jutras, B.L.; Chenail, A.M.; Stevenson, B. Changes in bacterial growth rate govern expression of Borrelia burgdorferi OspC and Erp infection-associated surface proteins. J. Bacteriol. 2013, 195, 757-764. [CrossRef] [PubMed]

175. Bransfield, R.C. The psychoimmunoloy of Lyme/tick-borne diseases and its association with neuropsychiatric symptoms. Open Neurol. J. 2012, 6, 88-93. [CrossRef] [PubMed] 
176. Jacek, E.; Fallon, B.A.; Chandra, A.; Crow, M.K.; Wormser, G.P.; Alaedini, A. Increased IFNa activity and differential antibody response in patients with a history of Lyme disease and persistent cognitive deficits. J. Neuroimmunol. 2013, 255, 85-91. [CrossRef] [PubMed]

177. Novak, P.; Felsenstein, D.; Mao, C.; Octavien, N.R.; Zubcevik, N. Association of small fiber neuropathy and post treatment Lyme disease syndrome. PLoS ONE 2019, 14, e0212222. [CrossRef]

178. Lochhead, R.B.; Arvikar, S.L.; Aversa, J.M.; Sadreyev, R.I.; Strle, K.; Steere, A.C. Robus interferon signature and suppressed tissue repair gene expression in synovial tissue from patients with postinfections, Borrelia-burgdorferi-induced Lyme arthritis. Cell. Microbiol. 2019, 21, e12954. [CrossRef]

179. Miller, J.C.; Von Lackum, K.; Woodman, M.E.; Stevenson, B. Detection of Borrelia burgdorferi gene expression during mammalian infection using transcriptional fusions that produce green fluorescent protein. Microb. Pathog. 2006, 41, 43-47. [CrossRef] 